\title{
NEWS
}

\section{Science outreach scheme ramps up}

The US National Lab Day programme has begun to gain traction after initial problems recruiting interested scientists. The initiative, first proposed last summer by President Barack Obama and the federal government's Office of Science and Technology Policy, aims to boost school children's interest in science by linking scientist volunteers with teachers, school administrators and students aged 6-17 years. Through its website (www. nationallabday.org), interested scientists or teachers can be paired up automatically or can choose a particular scientist or teacher partner.

Despite its name, National Lab Day is a long-term programme that began recruiting last November. Partner organizations include the National Institutes of Health (NIH), the American Chemical Society and the National Science Foundation. The Jack D. Hidary Foundation, the Bill \& Melinda Gates Foundation and the MacArthur Foundation have helped to fund the initiative.

$\mathrm{NIH}$ director Francis Collins lamented an initially poor response from scientists during his 13 March address at the annual meeting of the National Postdoctoral Association in Philadelphia, Pennsylvania. Concerned, Collins sent a message in early March to all
$\mathrm{NIH}$ employees and principal investigators on NIH grants, urging them to take part. The call-to-arms helped, according to Bruce Fuchs, director of the NIH Office of Science Education in Bethesda, Maryland. In January alone, 436 scientists and 826 teachers had signed up; in March, the number of scientists leapt to 1,022. As Naturejobs went to press, 2,518 scientists and 3,068 teachers had signed up in total.

From 1-12 May, participating communities will celebrate the collaborations, with activities culminating on $12 \mathrm{May}$. NIHfunded investigator Charles Brenner, head of biochemistry at the University of lowa's Carver College of Medicine in lowa City, learned about the initiative from Collins's message. He plans to visit classes of biology students aged $15-16$ at a local high school on 12 May, where he will use yeast to demonstrate cellular lifespan and to show cells' ability to form colonies at different ages. "They always find it interesting to look at cells under a microscope,"
Brenner says, recalling past visits.

Global warming will be the focus for climate scientist Thomas Charlock's live webcast on 22 April. Charlock's contribution is part of the National Lab Day efforts at the NASA Langley Research Center in Hampton, Virginia. He will demonstrate the difficulties of measuring atmospheric radiation, which affects climatechange predictions, to teachers of students aged 8-17. He hopes to incite student interest in the topic and maybe even motivate a future scientist to one day invent a better radiometer.

"A lot of kids, and teachers too, have no real idea of what scientists do and what science means," says Gina Schatteman, an American

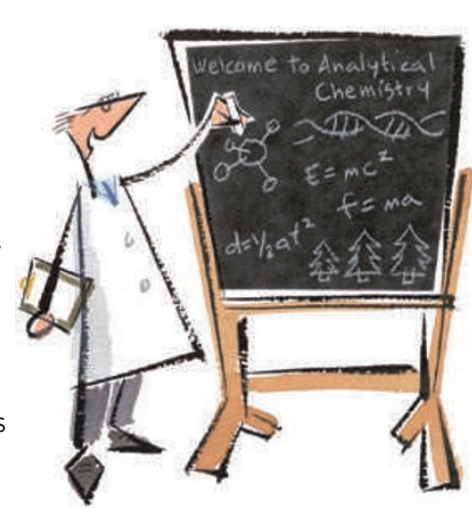
Advancement of Science policy fellow at the $\mathrm{NIH}$ Office of Science Education, who is on the programme's steering committee. "The Obama administration recognized that teachers and kids both need to understand the scientific process, and who better to show that than the people who do science themselves?"

Karen Kaplan

\section{PROSPECTS}

\section{The junior senior supervisor}

Mentoring students as a young researcher has its own particular challenges, suggests Fabio Paglieri.

During my time as a PhD student, my supervisor was a father figure - perhaps an easy role to accept, as he was about the same age as my parents. Now I find myself supervising half a dozen younger colleagues, some of them undergraduates, others seeking a PhD. The age difference between us is a matter of a few years, not decades. With my own undergraduate memories still vivid, I wonder what wisdom I can offer. Mentoring as a young researcher has its own challenges, including a lack of experience and some major conflicts of interest.

Behavioural experiments constitute much of the work we do in our lab, and requires a group effort. Without eager students running tests and collecting data, postdocs and faculty members would have no time to publish results. But the students of today are the scientists of tomorrow: we all share responsibility for their training. Collecting data is just a small part of that, and I feel compelled to involve them in proposing ideas, designing experiments and interpreting results, no matter how difficult that may be.
The greatest challenge is to teach them how to be independent thinkers; particularly for my students, who have spent years in an Italian educational system in which conformity is often prized and inventiveness disparaged. If scientists and others aspire to develop 'knowledge societies', we need to stop creating productionline researchers who follow the latest hype without hesitation. Instead, we need to start training scientists as intellectual leaders, charged with envisaging how society should change. I hope that this will happen, even though it does not fit well with the 'publish-or-perish' scenario.

So what advice should I give to my students? They first walk into our lab with eagerness and trepidation, awed to enter a research facility and to be entrusted with scientific responsibilities. I remember feeling the same. But I also know that, after years of uncertainty and scrambling over hurdles, only a fraction of them - the best, I hope - will make a living in research. As for the others, the chances are that their scientific training will not pay off outside academia. I fear that they might put their careers in jeopardy by chasing the same dream as me - a full-time position in research - while neglecting to consider alternative job opportunities.

That raises another concern: my own ambition. Still a postdoc myself, I'll probably find that the most talented of my younger colleagues will become my competitors. If so, I'm hardly in a position to offer impartial advice, no matter how pure my intentions are. With so many tangled responsibilities and loyalties, I think that candour is the best response. Never paint the future in false colours, never neglect talent, never promote mediocrity, never hide your own agenda, always assess students honestly, and let them chart their own career course. With luck, one day they'll remember us, if not as good fathers, then at least as decent older brothers.

Fabio Paglieri is a Postdoc Journal keeper for Naturejobs and a postdoc in cognitive psychology at the Institute for Cognitive Science and Technologies of the CNR in Rome, Italy. 